In order to make a very large number of determinations of $p \mathrm{H}$ of serum under the best possible conditions of accuracy, rapidity and ease, we developed a new rotating hydrogen electrode $\theta^{9}$, which enabled us to reach the third decimal point in about five minutes, with 0.4 c.c. of liquid. Three or four bubbles of hydrogen, containing carbon dioxide in equilibrium with the samples under experiment, are required. Good temperature control by circulating water around hydrogen and calomel electrode is provided.

Under such conditions we found that, after heating for 10 minutes in sealed tubes, a lowering of the $p H$ always takes place. The minimum is usually observed around $60^{\circ} \mathrm{C}$., but sometimes at $62^{\circ}$ and even $63^{\circ}$. After the minimum of acidification is reached, the value of the $p H$ fluctuates around this value, and sometimes shows a marked tendency towards higher $p H$ values (alkalinisation).

This is true of all sera studied so far (mammals), whether pure or diluted with isotonic solution, provided the serum is handled throughout under a layer of neutral paraffin oil in order to avoid the loss of carbon dioxide. Failure to prevent this loss explains the alkalinisation reported by previous workers, and the lack of sensitivity of the method of measurement accounts for absence of variation reported by the others. The amplitude of the drop in $p H$ is indeed small, and its mean value (more than four thousand experiments were made) is $0.05 p H$. The extremes observed were 0.03 and $0.07 p \mathrm{H}$.

Increase in the time of heating does not result in an increase in the amplitude of the drop. The only difference observed is its displacement towards lower temperatures: the minimum occurs around $58^{\circ}$. When the serum is diluted with isotonic solution before heating, the amplitude of the drop is increased (up to $0.1 p H$ ), and shifted towards higher tem. peratures, and the decrease begins around $55^{\circ}$.

Institut Pasteur,

P. LECOMTE DU NoÜY.

Paris.

Oct. 2.

${ }^{1}$ Lecomte du Noüy, Ann Inst. Pasteur, 42, 742; 1928. J. Gen. Physiol., 12, 363; 1929 .

${ }^{2}$ Lecomte du Noüy, Ann. Inst. Pasteur, 43, 749; 1929.

${ }^{3}$ Lecomte du Noüy, Ann. Inst. Pasteur, 44, 109; 1930.

- Lecomte du Noüy, Ann. Inst. Pasteur, 45, 251; 1930.

5 Lecomte du Noüy, Ann. Inst. Pasteur, 50, 127 ; 1933.

- Lecomte du Noüy, Ann. Inst. Pasteur, 48, 187; 1932.

'F. Seelich, Biochem. Z., 250, 549; 1932. 268, 34; 1934.

F. Seelich, Biochem. Z., (in press).

- Lecomte du Noüy, C.R. Acad. Sci., 193, 1417; 1931. Science, 75, 643; 1932

\section{Whales and Caisson Disease}

Prof. Krogh's interesting comments ${ }^{1}$ on the physiology of the blue whale and how it escapes caisson disease stimulate further speculation. Capt. Damant ${ }^{2}$ suggested that at ten atmospheres' pressure below the surface the whale's lungs and the gaseous contents might be compressed to one tenth of the normal volume and in this way the absorption of nitrogen might be retarded. Prof. Krogh replied that he could not picture the whale's thorax and lungs compressed to this extent.

There is another possibility not yet recorded so far as I know. When the whale submerges deeply it may not contain any gas in its lungs at all. It may fill its lungs with sea-water and in this way avoid all extreme compression of lung tissue. Also, as there is no free nitrogen gas in the lung, in such a case all danger of bubble formation in the tissues is excluded. This theory assumes that the whale is able to do without oxygen for considerable periods, after it has breathed at the surface. The animal may accumulate a considerable oxygen debt under water. The water freed from the whale when it blows has always appeared to me to be too substantial to be merely vapour mixed with air from the lungs. The whale may tolerate sea-water in its lungs.

\section{J. Argxll CAMpbell.}

National Institute for Medical Research,

Hampstead, London, N.W.3.

Oet. 8.

1 NATure, 133, 635, April 28, 1934.

2 ibid., p. 874

\section{Science at the Universities}

I AM grieved to infer, from his letter in NATURE of October 13, that Prof. Haldane thinks that I have no soul. The skittle that he knocks down with such gusto is not mine. If he had read my address with more care, he might have discovered that the remarks which he quotes have no bearing on the question how far a knowledge of biology is useful to the average citizen : they refer solely to the danger of encouraging too many students to study intensively a highly specialised branch of knowledge. Let me ask him two questions :

(1) Does he really think that a highly specialised training in any branch of knowledge is an essential ingredient of good citizenship ?

(2) Which is more likely to make a man a good citizen ? To find that the world wants him, or to find that it does not?

Prof. Haldane really ought not to stupefy himself with catch-phrases. He accuses me of regarding biologists as mere commodities. A commodity is a useful thing with a marketable value. I have not the least objection to being regarded as a commodity in that sense; nor have I any reason to believe that biologists, as a class, are more sensitive. What a "mere commodity" means, I do not know ; except that one says "mere" when one wants to be vaguely insulting. But the insult is Prof. Haldane's; not mine. He thinks that my opinions will encourage "revolutionary views" among university students. Let me assure him that it seldom worries a young man to find that he has a good marketable value; what worries him is to find by bitter experience, after years of intensive study, that he has little or no marketable value.

Oct. 15 .

H. T. Tuzard.

\section{The Philosophy of Sir James Jeans}

Dr. CampbelL ${ }^{1}$ seems himself to have missed the point. I agree with him (though I should not so express it) that "there is not nearly as much difference between the old and the new as Jeans, Eddington and their followers pretend". This was-obviously, I should have thought - my contention in the original article. The point at issue with Dr. Jeffreys is whether the "old" science realised its character so well as the "new"-quite a different thing.

${ }^{1}$ Nature, 134, 571, Oct. $13,1934$.

H. D. 